\title{
Assessment of Cellular Responses in Kidney Cells Exposed to Cobalt Oxide Nanoparticles
}

\author{
Mahmoud Abudayyak, Tuba Altınçekiç Gürkaynak, Gül Özhan
}

\begin{abstract}
Cobalt oxide $\left(\mathrm{Co}_{3} \mathrm{O}_{4}\right)$ nanoparticles have been extensively used in various industrial and medical applications due to their special optical, magnetic, and electrical activity features. However, there is a lack of information about their toxicity and adverse effects on human health, especially concerning the kidney, which is considered to be a secondary target organ. We investigated the toxic potentials of $\mathrm{Co}_{3} \mathrm{O}_{4}$ nanoparticles on NRK-52E kidney epithelial cells by in vitro assays. $\mathrm{Co}_{3} \mathrm{O}_{4}$
\end{abstract}

nanoparticles were taken up by the kidney cells, and caused a decrease in cell viability, by significantly inducing apoptosis/ necrosis at $100 \mu \mathrm{g} / \mathrm{mL}$. However, no significant DNA damage was observed. $\mathrm{Co}_{3} \mathrm{O}_{4}$ nanoparticles induced cellular toxicity in kidney cells. These results should raise concern about the safety of $\mathrm{Co}_{3} \mathrm{O}_{4}$ nanoparticles in their various applications. Further studies are needed to elucidate their toxic mechanism.

Keywords: Genotoxicity; Cytotoxicity; Apoptosis; Nanoparticle; Cobalt oxide.
Mahmoud Abudayyak

Istanbul University, Faculty of Pharmacy, Department of Pharmaceutical

Toxicology, Beyazit 34116, Istanbul-Turkey

Tuba Altınçekiç Gürkaynak

Istanbul University, Faculty of Engineering, Department of Chemical Engineering, Avcilar, 34850, Istanbul-Turkey.

Mahmoud Abudayyak, Gül Özhan

Karadeniz Technical University, Faculty of Pharmacy, Department of Pharmaceutical Toxicology, 61000, Trabzon-Turkey (permanent address)

Corresponding Author:

Gül Özhan

e-mail:gulozhan@istanbul.edu.tr

Submitted / Gönderilme: 06.02 .2017

Accepted / Kabul: $\quad$ 07.03.23017
Revised / Düzeltme: 03.03.2017

\section{INTRODUCTION}

Nanotechnological products have been used widely in fields ranging from medicine to industry because of their physicochemical properties. However, the human and environmental concern are gradually increased [1]. It is well known that nanoparticles be absorbed through the skin, ingested, and inhaled during occupational and/or environmental applications [2]. With systemic administration, nanoparticles could penetrate from biological membranes. For instance, cobalt (Co)-based nanoparticles easily penetrate and cause damage to the skin more than the bulk material itself [3]. In addition, direct exposure to the bulk materials that are used in various fields can indirectly expose humans to their nanoparticles [4].

Co-based nanoparticles are used in different technological products including sensors, catalysts, pigments, and magnetism and energy storage devices [5-6]. The Co intake in food has been estimated to be $5-40 \mathrm{mg} /$ day [7]. A study that include 970 exposure measurements in Japan reported Co exposures of ambient personal monitoring of 1-6400 mg/ $\mathrm{m}^{3}$ [8]. Similar levels were found in the range of $0.9-81 \mathrm{mg} /$ $\mathrm{m}^{3}$ in a German study [9], and levels of $2-240 \mathrm{mg} / \mathrm{m}^{3}$ in a study from the United States [10]. In a Finnish study, 8-hour time-weighted average (TWA) levels were $2-240 \mathrm{mg} / \mathrm{m}^{3}$ [11]. 
The use of Co is favoured in nanomedicine and nanotechnology due to its enhanced magnetic properties, although it is reported $\mathrm{Co}_{3} \mathrm{O}_{4}$ is highly toxic and is classified as possibly carcinogenic to humans (Group 2B) by the International Agency for Research on Cancer (IARC) [1213]. Prolonged exposure of rats and rabbits to $\mathrm{Co}_{3} \mathrm{O}_{4}(0.4-9$ $\mathrm{mg} \mathrm{Co} / \mathrm{m}^{3}$ ) resulted in lesions in the alveolar region of the respiratory tract [14]. Also, lifetime exposure of hamsters to $\mathrm{Co}_{3} \mathrm{O}_{4}\left(7.9 \mathrm{mg} \mathrm{Co} / \mathrm{m}^{3}\right)$ resulted in emphysema [15]. Primary respiratory effects in occupationally exposed humans have been reported as ranging from 0.015 to $0.13 \mathrm{mg} \mathrm{Co} /$ $\mathrm{m}^{3}$ [7]. The no-observed-adverse-effect-level (NOAEL) for chronic inhalation exposure was $0.0053 \mathrm{mg} \mathrm{Co} / \mathrm{m}^{3}$ [7]. The acute median lethal concentration $\left(\mathrm{LC}_{50}\right)$ for a 30-minute inhalation exposure in rats was $165 \mathrm{mg} \mathrm{Co} / \mathrm{m}^{3}$ [16]. In South Africa, the highest concentrations of cobalt in ambient air and in urine samples of workers were $9.9 \mathrm{mg} / \mathrm{m}^{3}$ and 712 $\mu \mathrm{g} / \mathrm{g}$ creatinine, respectively [17]. In previous studies, it has been reported that $\mathrm{Co}_{3} \mathrm{O}_{4}$ particles were readily taken up through endocytosis and were partially solubilized at the low $\mathrm{pH}$ within lysomes [18-19].

Nanoparticles can affect the cell macromolecules, and have a role in oxidative stress, DNA damage, cell function and morphological change in the exposed organ or system such as lung, liver, kidney, and gastrointestinal and nervous systems [20]. $\mathrm{Co}_{3} \mathrm{O}_{4}$, one of the most interesting and widely used CoNPs, might induce oxidative stress [19], DNA damage and genotoxicity [21-22], cell death, and inflammatory responses [23-25]. It was reported that occupational exposure to CoNPs has been associated with adverse health effects including rhinitis, asthma, allergic dermatitis, and cardiomyopathy [26]. As the previous studies have been reported, As it is well known, nanoparticle toxicity is still controversial and depends on cell type sensitivity, method and condition of exposure, as well as nanoparticle characterisation [27-28]. In addition, there have been no studies concerning the nephrotoxicity of $\mathrm{Co}_{3} \mathrm{O}_{4}$ nanoparticles. In this study, we aimed to evaluate by in vitro assays the toxic effects of $\mathrm{Co}_{3} \mathrm{O}_{4}$ nanoparticles on kidney (NRK-52E) cells.

\section{MATERIALS AND METHODS}

Chemicals: $\mathrm{Co}_{3} \mathrm{O}_{4}$, neutral red dye, triton X-100 and MTT (3-[4,5-dimethylthiazol-2-yl]-2,5-diphenyl-tetrazolium bromide) were from Sigma Chemical Co. Ltd. (St. Louis, MO, USA). Cell culture medium (DMEM F-12) and all other supplements were from Multicell Wisent (Quebec, Canada). Annexin V-FITC apoptosis (AV) detection kit with propidium iodide (PI) was from Exbio (Vestec, Czech Republic). The other chemicals were from Merck (NJ, USA).

Particle size characterisation: $\mathrm{Co}_{3} \mathrm{O}_{4}$ nanoparticles were suspended in milli-Q water and cell culture medium with $10 \%$ fetal bovine serum (FBS), and thentheir particle size and distribution were measured by Transmission Electron Microscopy (TEM) (Jem-2100 HR, Jeol, USA) [29-31].

Cell culture and exposure condition: In the study, NRK52E rat kidney proximal tubular epithelial cells (CRL-1571) was purchased from the American Type Culture Collection (ATCC). The cells were incubated in DMEM-12 medium supplemented with $\mathrm{FBS}$ and antibiotics at 5\% $\mathrm{CO}_{2}, 90 \%$ humidity and $37^{\circ} \mathrm{C}$ for $24 \mathrm{~h}$. The cell densities were $1 \times 10^{6}$ cells $/ \mathrm{mL}$ in all assays. $\mathrm{Co}_{3} \mathrm{O}_{4}$ nanoparticles were freshly suspended at $1 \mathrm{mg} / \mathrm{mL}$ concentration in cell culture medium with $10 \% \mathrm{FBS}$ and sonicated at room temperature for $15 \mathrm{~min}$ to avoid the aggregation/agglomeration of the nanoparticles before use [29-31]. The cell exposed final concentrations of $0-750 \mu \mathrm{g} / \mathrm{mL}$ in the cytotoxicity assays, $0-100 \mu \mathrm{g} / \mathrm{mL}$ in genotoxicity assay, $0-100 \mu \mathrm{g} / \mathrm{mL}$ in apoptosis/necrosis assay, and $200 \mu \mathrm{g} / \mathrm{mLin}$ the cellular uptake assay [30]. The exposure time to the particle suspension was $24 \mathrm{~h}$.

Cellular uptake by Inductively Coupled Plasma-Mass Spectrometry (ICP-MS): To determine cellular uptake of $\mathrm{Co}_{3} \mathrm{O}_{4}$ nanoparticles, the NRK-52E cells were exposed to 200 $\mu \mathrm{g} / \mathrm{mL}$ concentration of the particle suspensions. The cells were prepared as to Abudayyak et al. [29-30], and counted by Luna cell counter (Virginia, USA). The samples were assayed for Co amount by using ICP-MS (Thermo Elemental Xseries 2, USA). Also, Co content of the untreated cells was measured.

Cytotoxicity evaluation: The cytotoxic potential of $\mathrm{Co}_{3} \mathrm{O}_{4}$ nanoparticles was determined by MTT and neutral red uptake (NRU) cytotoxicity assays, and AV apoptosis detection assay with PI. By these assays, the induction potential of the particles on metabolism alteration and apoptosis were observed [29-33]. The cell exposed final concentrations of 0 , $25,50,100,250,500$ and $750 \mu \mathrm{g} / \mathrm{mL}$. Optical density (OD) was read by a microplate spectrophotometer system (Epoch, Germany). In every assay, the untreated cells were evaluated as control. It was calculated the inhibition of enzyme activity observed in cells compared to negative control (1\% PBS) cells.

To determine the apoptosis induced potentials of $\mathrm{Co}_{3} \mathrm{O}_{4}$ nanoparticles, it was determined by AV apoptosis detection kit with PI according to supplier instruction. In the assay, it was enabled viable ( $\left.\mathrm{AV}^{\text {negative }} / \mathrm{PI}^{\text {negative }}\right)$, apoptotic ( $\mathrm{AV} \mathrm{V}^{\text {positive }}$ 
/ $\left.\mathrm{PI}^{\text {negative }}\right)$ or $\left(\mathrm{AV}^{\text {positive }} / \mathrm{PI}^{\text {positive }}\right)$ and necrotic (AV $\mathrm{Angative}^{\text {/ }}$ $\left.\mathrm{PI}^{\text {positive }}\right)$ cells to be distinguished. The cell exposed final concentrations of $0,0.1,10$ and $100 \mu \mathrm{g} / \mathrm{mL}$ in the apoptosis/ necrosis assay [29-30]. The cells were distributed on the slides and immediately counted under a phase-contrast fluorescent microscope (Olympus BX53, Tokyo, Japan). The cells incubated at $55^{\circ} \mathrm{C}$ for $20 \mathrm{~min}$ were evaluated as positive control. The untreated cells were used as negative control to define the basal level of the apoptotic cells. The percentage of cells induced to apoptosis was determined by substracting the percentage of apoptotic cells in the untreated cells from percentage of apoptotic cells in the treated cells. Results were expressed as percent of the total cell amount.

Genotoxicity evaluation: The genotoxic potential of $\mathrm{Co}_{3} \mathrm{O}_{4}$ nanoparticles was determined by comet assay [29-31, 34]. The cells were exposed to final concentrations of $0,0.1$, 10 and $100 \mu \mathrm{g} / \mathrm{mL}$. Hydrogen peroxide $\left(\mathrm{H}_{2} \mathrm{O}_{2}\right)(100 \mu \mathrm{M})$ and PBS (1\%) were used as positive and negative controls, respectively [29-31]. The number of DNA breaks were scored under a fluorescent microscope (Olympus BX53, Tokyo, Japan) at 400 magnifications by using an automated image analysis system (Comet Assay IV, Perceptive Instruments, Suffolk, UK). DNA damage to individual cells was expressed as a percentage of DNA in the comet tail intensity.

Statistical analysis: All experiments were done in triplicates and each assay was repeated three time. Data was expressed as mean \pm standard deviation (SD). The significance of differences between untreated (negative control) and treated cells with nanoparticles was calculated by one-way ANOVA Dunnett t-test using SPSS version 17.0 for Windows (SPSS Inc., Chicago, IL). $p$ values of less than 0.05 were selected as the levels of significance.

\section{RESULTS AND DISCUSSION}

According to the results of TEM analysis, the average size of $\mathrm{Co}_{3} \mathrm{O}_{4}$ nanoparticles was $39 \pm 21 \mathrm{~nm}$ in water with narrow size distribution. When the particle size distribution was evaluated after dispersion in culture medium, the nanoparticles were observed to be slightly agglomerated and/or aggregated in the cell culture medium. Their average sizes (range) were increased to $101.5 \mathrm{~nm}$ (32.6-157.1 $\mathrm{nm}$ ) (Figure 1). With ICP-MS, we observed that $\mathrm{Co}_{3} \mathrm{O}_{4}$ nanoparticles were taken up by NRK-52E kidney cells. The mean Co amount in the intracellular fluid was $1.5 \mu \mathrm{g} / \mathrm{mL} / 10^{5}$ cells. We observed that $\mathrm{Co}_{3} \mathrm{O}_{4}$ nanoparticles decreased the cell metabolic activity with mitochondrial and lysosomal dysfunctions with in a concentrationdependent manner (Figure 2). The $\mathrm{IC}_{50}$ value of $\mathrm{Co}_{3} \mathrm{O}_{4}$ nanoparticles on NRK52E cells was $312.75 \mu \mathrm{g} / \mathrm{mL}$ by MTT assay. According to NRU assay results, the maximum observed cellular death was $21.63 \%$ at the maximum exposure concentration of 750 $\mu \mathrm{g} / \mathrm{mL}$. According to these results, we indicate that kidney cells could be a sensitive target due to the cytotoxic effect of $\mathrm{Co}_{3} \mathrm{O}_{4}$ nanoparticles on mitochondrial function. Alinovi et al. [13] compared the cytotoxic effects of titanium dioxide $\left(\mathrm{TiO}_{2}\right)$ and $\mathrm{Co}_{3} \mathrm{O}_{4}$ nanoparticles on human aortic and umbilical vein endothelial cells. They observed $\mathrm{TiO}_{2}$ nanoparticles showed few acute cytotoxic effects even at very high concentrations, whereas $\mathrm{Co}_{3} \mathrm{O}_{4}$ nanoparticles impaired cell metabolism in a concentration- and timedependent manner. Alarifi et al. [5] reported that $\mathrm{Co}_{3} \mathrm{O}_{4}$ nanoparticles had a cytotoxic effect on HepG2 liver cells (46.0\% cell death at $25 \mu \mathrm{g} / \mathrm{mL}$ for $24 \mathrm{~h} ; 62.0 \%$ cell death at $25 \mu \mathrm{g} / \mathrm{mL}$ for $48 \mathrm{~h}$ ). Similarly, Petrarca et al. [25] observed that $\mathrm{Co}_{3} \mathrm{O}_{4}$ nanoparticles were cytotoxic on leukemic cancer cells $\left(\mathrm{IC}_{50}\right.$ value $\left.\leq 21.3 \mu \mathrm{g} / \mathrm{mL}\right)$.

In the present study, $\mathrm{Co}_{3} \mathrm{O}_{4}$ nanoparticles induced significant cell death by apoptosis and necrosis on NRK-52E cells ( $p$ $\leq 0.05$ ). Apoptosis and necrosis frequencies were observed in $70.04 \%$ and $29.38 \%$ of the dead cells respectively, at an exposure concentration of $100 \mu \mathrm{g} / \mathrm{mL}$. $\mathrm{Co}_{3} \mathrm{O}_{4}$ nanoparticles induced apoptosis ( $\leq 10.64$-fold) as well as necrosis $(\leq 3.69$ fold) in NRK-52E cells compared with negative control cells (Figure 3). Similarly, $\mathrm{Co}_{3} \mathrm{O}_{4}$ nanoparticles induced apoptosis (at $10-25 \mu \mathrm{g} / \mathrm{mL}$ ) in leukemic cancer cells [24]. Spigoni et al. [35] reported that $\mathrm{Co}_{3} \mathrm{O}_{4}$ nanoparticles significantly reduced cell viability, and induced apoptosis, oxidative stress, caspase activity, and pro-inflammatory cytokine gene expression in vitro. They indicated that the adverse effects might be relevant for a potential role of exposure to titanium dioxide $\left(\mathrm{TiO}_{2}\right)$ and $\mathrm{Co}_{3} \mathrm{O}_{4}$ nanoparticles in enhancing cardiovascular risk in humans. Chattopadhyay et al. $[24,28]$ found that $\mathrm{Co}_{3} \mathrm{O}_{4}$ nanoparticles significantly induced cell death generated by ROS, which induced tumor necrosis factor- $\alpha$ (TNF- $\alpha$ ) by activating pro-apoptotic factors (p38-MAPK, caspase-8, and caspase-3).

In contrast to our results with cytotoxic potential of $\mathrm{Co}_{3} \mathrm{O}_{4}$ nanoparticles, the particles were observed not to induce DNA damage. No significant differences were found in tail intensity. The tail intensities observed were $16.90( \pm 0.74)$ and $3.71( \pm 0.42)$ for positive $\left(100 \mu \mathrm{M} \mathrm{H}_{2} \mathrm{O}_{2}\right)$ and negative control (1\% PBS) groups, respectively (Figure 4). However, there are some opposite results in the literature. Alarifi et al. [5] indicated that $\mathrm{Co}_{3} \mathrm{O}_{4}$ nanoparticles showed a statistically 
Figure 1: TEM images of $\mathrm{Co}_{3} \mathrm{O}_{4}$ nanoparticles in water (a), cell culture medium (b) and the size distributions of $\mathrm{Co}_{3} \mathrm{O}_{4}$ nanoparticles in water and cell culture medium by TEM analysis (c).
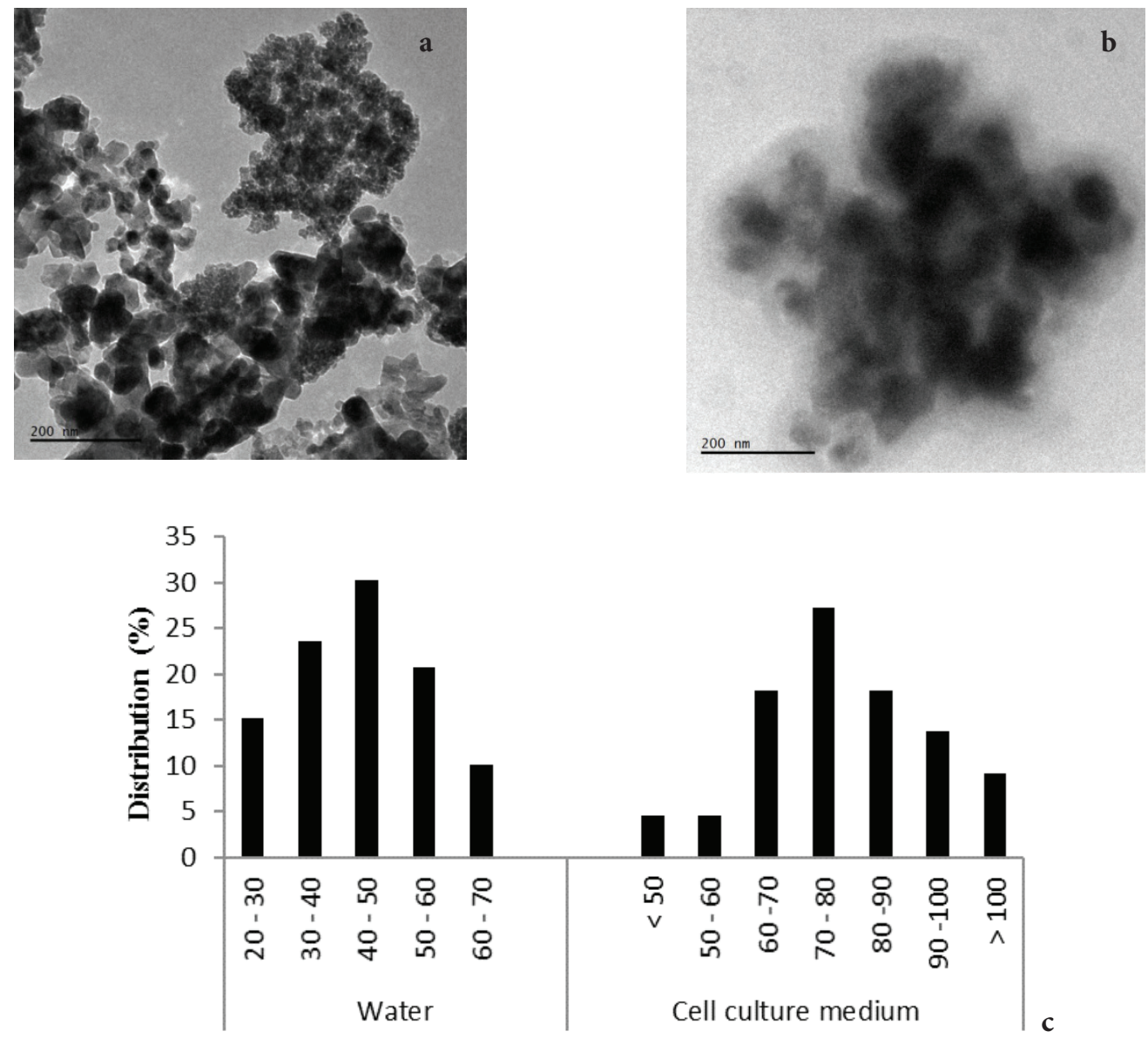

Particle average size (nm)

Figure 2: Effect of $\mathrm{Co}_{3} \mathrm{O}_{4}$-Nanoparticles on cell viability by MTT and NRU assays.

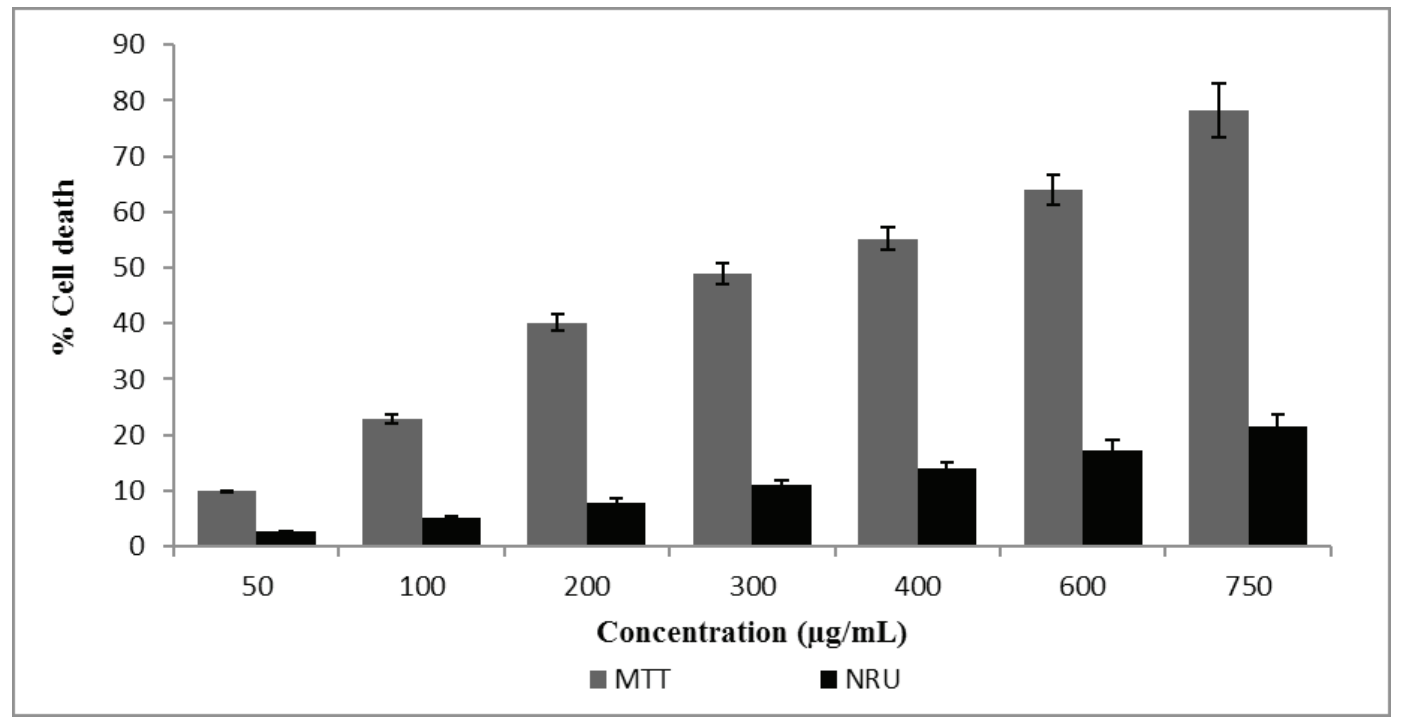

All experiments were done in triplicates and each assay was repeated four times. The results were presented as mean with $\pm \mathrm{SD}$. 
Figure 3: Evaluation on the apoptosis- and necrosis-inducing potentials of $\mathrm{Co}_{3} \mathrm{O}_{4}$ nanoparticles using $\mathrm{AV}$ apoptosis detection assay with PI.

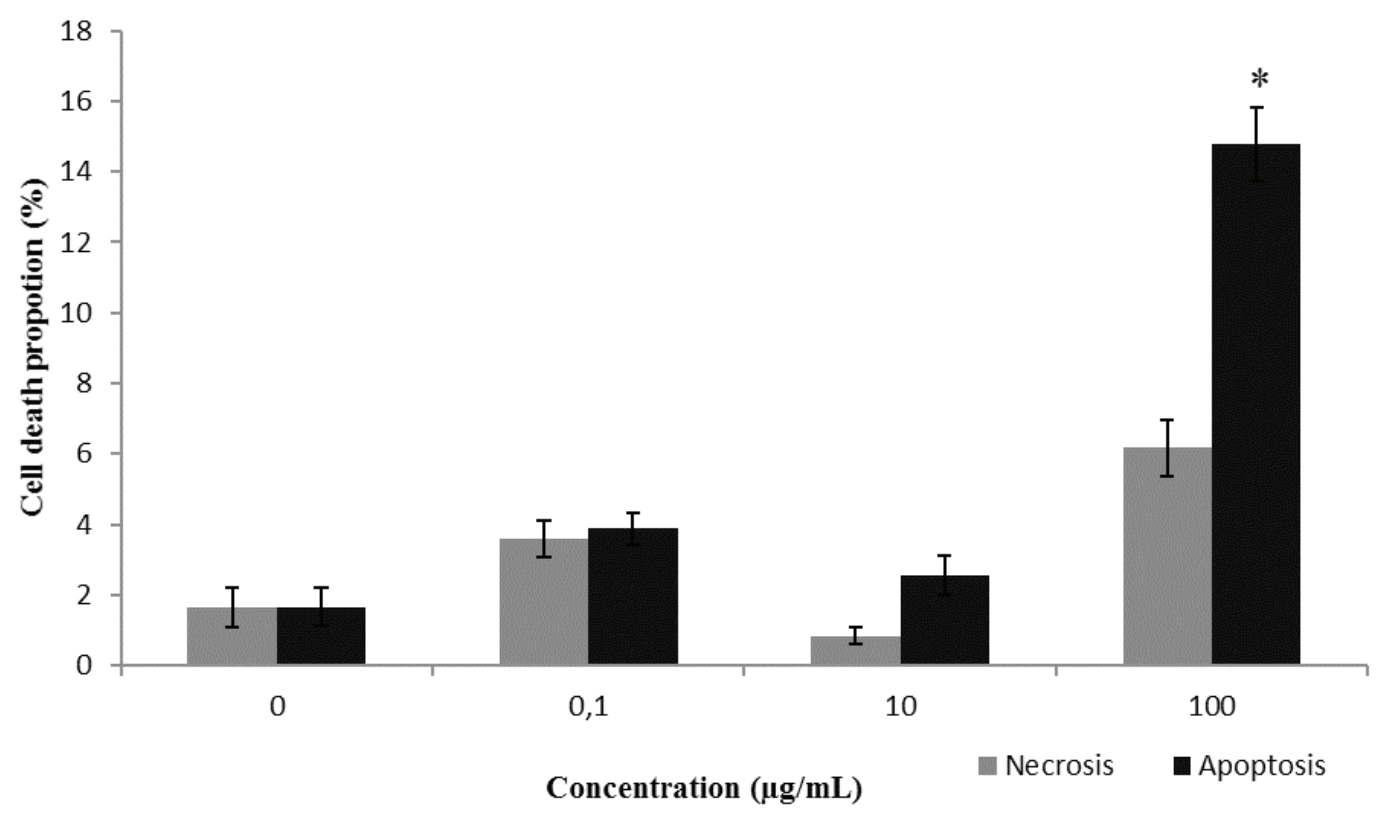

All experiments were done in triplicates and each assay was repeated three times. The results are presented as percentage of the total cell amount with \pm SD.

${ }^{*} p \leq 0.05$ were selected as the levels of significance by one-way ANOVA Dunnett t-test.

Figure 4: Evaluation of DNA damage potentials of $\mathrm{Co}_{3} \mathrm{O}_{4}$ nanoparticles using comet assay.

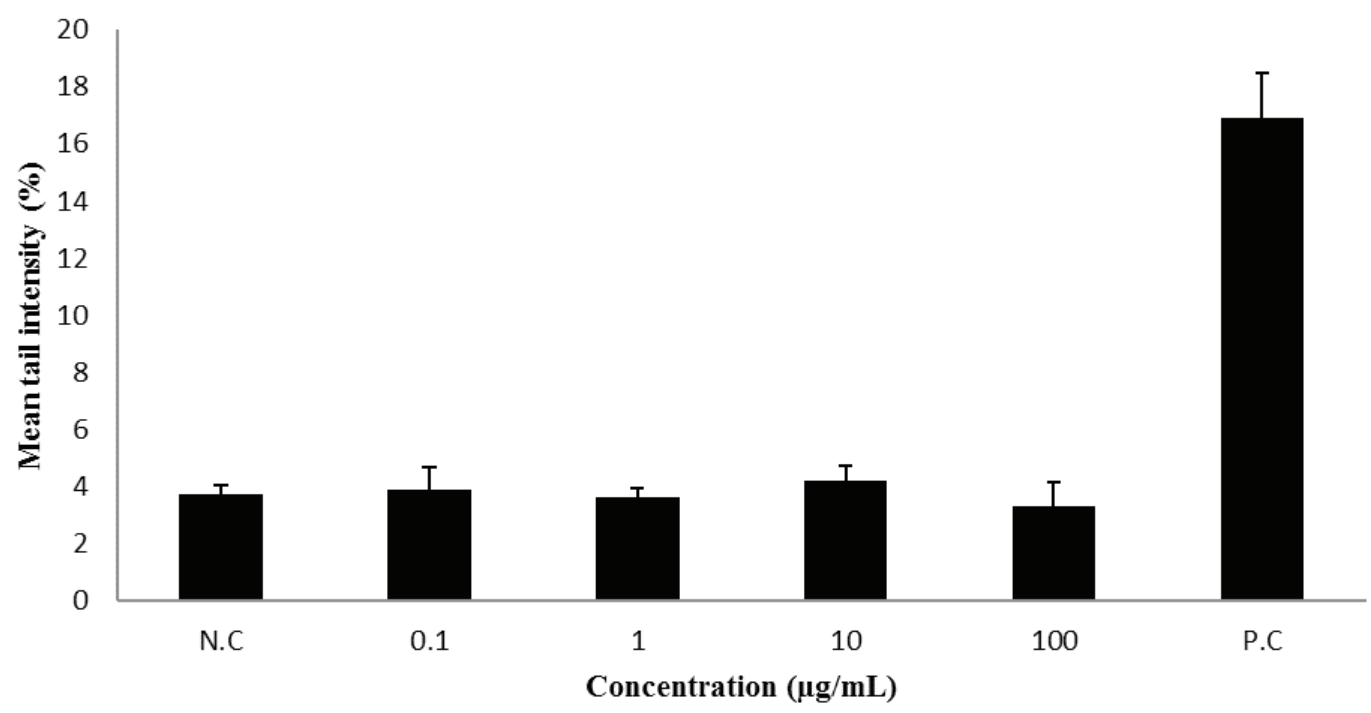

Experiments were done in triplicates and each was repeated three times. The results are presented as mean tail intensity (\%) with \pm SD.

N.C and P.C are negative and positive controls, respectively.

${ }^{*} p \leq 0.05$ were selected as the levels of significance by one-way ANOVA Dunnett t-test. 
significant dose- and time-related increase in DNA damage. Also, $\mathrm{Co}_{3} \mathrm{O}_{4}$ nanoparticles caused DNA damage (12.0-24.1 $\mathrm{mg} / \mathrm{mL}$ ) in human leukocytes and chromosomal aberration $(100 \mathrm{mg} / \mathrm{mL})$ in human lymphocytes through interacting with DNA and producing reactive oxygen species (ROS) in vitro [21,35]. Alarifi et al. [5] reported that $\mathrm{Co}_{3} \mathrm{O}_{4}$ nanoparticles caused a significant reduction in GSH with a concomitant increase in lipid hydroperoxide, ROS generation, superoxide dismutase, and catalase activities at 24 and 48 hours. Similarly, $\mathrm{Co}_{3} \mathrm{O}_{4}$ nanoparticles induced impairment of cellular viability and caused rapid induction of ROS with high levels $[19,36]$.

Finally, there are few in vivo studies about the nephrotoxicity profiles of $\mathrm{Co}_{3} \mathrm{O}_{4}$ nanoparticles. In rats with $5 \mathrm{mg}$ of metallic Co powder or Co sulphide powder injected into each pole of the right kidney, necropsies were conducted after 12 months, and no tumours were observed in the kidneys of treated or control rats [37]. Rats injected intraperitoneally with Co at 3 or $6 \mathrm{mg} / \mathrm{kg}$ body weight exhibited increased levels of oxidatively damaged

Kobalt Oksit Nanopartiküllerine Maruz Bırakılan Böbrek Hücrelerindeki Hücresel Cevabın Değerlendirilmesi

ÖZ

Kobalt oksit (Co3O4) nanopartikülleri spesifik optik, magnetik ve elektriksel aktivite özelliklerinden dolayı çeşitli endüstriyel ve medikal alanda geniş ölçüde kullanılmaktadır. Ancak, özellikle sekonder hedef organ olarak değerlendirilen böbreklerdeki etkiler göz önüne alındığında toksik ve advers etkileri açısından literatürde yeteri kadar bilgi mevcut değildir. Bu sebeple; Co3O4 nanopartiküllerinin NRK-52E böbrek epitel hücreleri üzerinde toksik potansiyelini in vitro şartlarda araştırdık. Böbrek hücreleri tarafından alınan Co3O4 nanopartiküllerinin $100 \mu \mathrm{g} /$

\section{REFERENCES}

1. Barillet S, Jugan ML, Laye M, Leconte Y, Herlin-Boime N, Reynaud C, Carrière M. In vitro evaluation of $\mathrm{SiC}$ nanoparticles impact on A549 pulmonary cells: cyto-, genotoxicity and oxidative stress. Toxicol Lett 2010; 20: 324-30.

2. Kim YJ, Yu M, Park HO, Yang SI. Comparative study of cytotoxicity, oxidative stress and genotoxicity induced by silica nanomaterials in human neuronal cell line. Mol Cell Toxicol 2010; 6: 337-44.

3. Filon LF, Crosera M, Timeus E, Adami G, Bovenzi M, Ponti J, Maina G. Human skin penetration of cobalt nanoparticles through intact and damaged skin. Toxicol Vitro 2013;27: 121-7.

4. Arora S, Rajwade JM, Paknikar KM. Nanotoxicology and in vitro studies: the need of the hour. Toxicol Appl Pharmacol 2012; 258: 151-65.

5. Alarifi S, Ali D, Verma A, Alakhtani S, Ali BA. Cytotoxicity and genotoxicity of copper oxide nanoparticles in human skin keratinocytes cells. Int J Toxicol 2013; 32: 296-307.
DNA bases in the liver, kidney, and lung at 2 and 10 days following injection [38].

In conclusion; we did not notice a correlation between the cell death (apoptosis or necrosis) and the genetic damage. However, we observed $\mathrm{Co}_{3} \mathrm{O}_{4}$ nanoparticles to be significantly induced cell death, presumably via the other pathways. $\mathrm{Co}_{3} \mathrm{O}_{4}$ nanoparticles should raise concern about their safety in various applications because the nanoparticles could be possessed of toxicological risk on kidney via cell death, DNA damage and apoptotic effects. However, the results need to be supported with in vivo studies to fully understand the mechanism even if the findings are the first results of $\mathrm{Co}_{3} \mathrm{O}_{4}$ nanoparticle neurotoxicity profiles.

Conflict of interest: Authors declare there is no conflict of interest.

Disclosure: This work was supported by the Research Fund of Istanbul University (Project No: 40441). Materials and methods has been reproduced the authors article puplished in from Biological Trace Element Research 2017, 175(2):458-465.

$\mathrm{mL}$ maruziyet konsantrasyonunda anlamlı düzeyde apoptoz ve nekrozu indükleyerek hücre canlılığında azalmaya sebep olduğu gözlendi. Buna karşılık, DNA'da hasara yol açmadığı tespit edildi. Elde edilen sonuçlara göre; $\mathrm{Co3O} 4$ nanopartiküllerinin böbrek hücrelerinde hücresel toksisiteyi indüklemesi çeşitli alanlardaki kullanımlarında $\mathrm{Co} 3 \mathrm{O} 4$ nanopartiküllerinin güvenliliğine temkinli yaklaşılması uygun olacaktır. Ancak, ileri çalışmalar ile toksik etki mekanizmalarının detaylı araştırılması gerekmektedir.

Anahtar Kelimeler: Genotoksisite; Sitotoksisite; Apoptoz; Nanopartikül; Kobalt oksit.

6. Alinovi R, Goldoni M, Pinelli S, Campanini M, Aliatis I, Bersani D, Lottici PP, Iavicoli S, Petyx M, Mozzoni P, Mutti A. Oxidative and pro-inflammatory effects of cobalt and titanium oxide nanoparticles on aortic and venous endothelial cells. Toxicol Vitro 2015; 29: 426-37.

7. Agency for Toxic Substances and Disease Registry (ATSDR). Toxicological profile for cobalt. Atlanta, GA: U.S. Department of Health and Human Services. [The ATSDR toxicological profile succinctly characterizes the toxicologic and adverse health effects information for cobalt].

8. Kumagai S, Kusaka Y, Goto S. Cobalt exposure level and variability in the hard metal industry of Japan. Am Ind Hyg Assoc J 1996; 57: 365-9.

9. Kraus T, Schramel P, Schaller KH, Zöbelein P, Weber A, Angerer J.Exposure assessment in the hard metal manufacturing industry with special regard to tungsten and its compounds. Occup Environ Med 2001; 58: 631-4. 
10. ACGIH. Threshold limits value for chemical substances and physical agents and biological exposure indices. Cincinnati: American Conference of Governmental Industrial Hygienists, 2015.

11. Linnainmaa M, Kangas J, Kalliokoski P. Exposure to airborne metals in the manufacture and maintenance of hard metal and stellite blades. Am Ind Hyg Assoc J 1996; 57: 196-201.

12. IARC. 2001. Some internally deposited radionuclides. International Agency for Research on Cancer. http://193.51.164.11/htdocs/Monographs/Vol78/Vol78radionuclides.html. June 7, 2001.

13. Johansson A, Curstedt T, Camner P. 1991. Lung lesions after combined inhalation of cobalt and nickel. Environ Res 1991; 54: 24-38.

14. Wehner AP, Busch RH, Olson RJ, Craig DK. Chronic inhalation of cobalt oxide and cigarette smoke by hamsters. Am Ind Hyg Assoc J 1997; 38: 338-46.

15. Palmes ED, Nelson N, Laskin S, Kuschner M. Inhalation toxicity of cobalt hydrocarbonyl. Am Ind Hyg Assoc J 1959; 20: 453-68.

16. Coombs, M. Biological monitoring of cobalt oxide workers. Int Arch Occup Environ Health 1996; 68: 511-2.

17. Al Samri MT, Silva R, Almarzooqi S, Albawardi A, Othman ARD, Al Hanjeri RSMS, Al Dawaar SKM, Tariq S, Souid AK, Asefa T. Lung toxicities of core-shell nanoparticles composed of carbon, cobalt, and silica. Int J Nanomedicine 2013; 8: 122344.

18. Ortega R, Bresson C, Darolles C, Gautier C, Roudeau S, Perrin L, Janin M, Floriani M, Aloin V, Carmona A, Malard V. Lowsolubility particles and a Trojanhorse type mechanism of toxicity: the case of cobalt oxide on human lung cells. Part Fibre Toxicol 2014; 11:14.

19. Papis E, Rossi F, Raspanti M, Dalle-Donne I, Colombo G, Milzani A, Bernardini G, Gornati R. Engineered cobalt oxide nanoparticles readily enter cells. Toxicol Lett 2009; 189: 253-9.

20. Chen X, Zhouhua W, Jie Z, Xinlu F, Jinqiang L, Qiu Yuwen, Zhiying H. Renal interstitial fibrosis induced by high-dose mesoporous silica nanoparticles via the NF- $\kappa \mathrm{B}$ signaling pathway. Int J Nanomedicine 2015; 10: 1-22.

21. Colognato R, Bonelli A, Ponti J, Farina M, Bergamaschi E, Sabbioni E, Miqliore L. Comparative genotoxicity of cobalt nanoparticles and ions on human peripheral leukocytes in vitro. Mutagenesis 2008; 23: 377-82.

22. Ponti J, Broggi F, Marmorato P, Franchini F, Colognato R, Rossi F. Genotoxicity and morphological transformation induced by cobalt nanoparticles and cobalt chloride: an in vitro study in Balb/3T3 mouse fibroblasts. Mutagenesis 2009; 24: 439-45.

23. Busch W, Kühnel D, Schirmer K, Scholz S, Schirmer K. Tungsten carbide cobalt nanoparticles exert hypoxia-like effects on the gene expression level in human keratinocytes. BMC Genomics 2010; 11: 65.

24. Chattopadhyay S, Dash SK, Tripathy S, Das B, Mahapatra SK, Pramanik P, Roy S. Cobalt oxide nanoparticles induced oxidative stress linked to activation of TNF- $\alpha$ /caspase-8/ p38-MAPK signaling in human leukemia cells. J Appl Toxicol 2015; 35: 603-13.
25. Petrarca C, Perrone A, Verna N, Verginelli F, Ponti J, Sabbioni E, Di Giampaolo L, Dadorante V, Schiavone C, Boscolo P, Costantini R, Di Gioacchino M. Cobalt nano-particles modulate cytokine in vitro release by human mononuclear cells mimicking autoimmune disease. Int J Immunopathol Pharmacol 2006; 19: 11-4.

26. Klasson M, Bryngelsson IL, Petterson C, Husby B, Arvidsson $\mathrm{H}$, Westberg H. Occupational exposure to cobalt and tungsten in the Swedish hard metal industry: air concentrations of particle mass, number, and surface area. Ann Occup Hyg 2016; 60(6): 684-99.

27. Horev-Azaria L, Kirkpatrick CJ, Korenstein R, Marche PN, Maimon O, Ponti J, Romano R, Rossi F, Golla-Schindler U, Sommer D, Uboldi C, Unger RE, Villiers C. Predictive toxicology of cobalt nanoparticles and ions: comparative in vitro study of different cellular models using methods of knowledge discovery from data. Toxicol Sci 2011; 122: 489501.

28. Chattopadhyay S, Dash SK, Tripathy S, Das B, Mandal D, Pramanik P, Roy S. Toxicity of cobalt oxide nanoparticles to normal cells; an in vitro and in vivo study. Chem Biol Interact 2015; 226: 58-71.

29. Abudayyak M, Altıncekic T, Özhan G. In vitro toxicological assessment of cobalt ferrite nanoparticles in several mammalian cell types. Biol Trace Elem Res 2017; 175: 458-65.

30. Abudayyak M, Guzel EE, Özhan G. Copper (II) oxide nanoparticles induced nephrotoxicity in vitro conditions. Appl Vitro Toxicol 2016; 2: 157-64.

31. Uzar NK Abudayyak M, Akcay N, Algun G, Özhan G. Zinc oxide nanoparticles induced cyto- and genotoxicity in kidney epithelial cells. Toxicol Mech Methods 2015; 25: 334-9.

32. Van Meerloo J, Kaspers GJL, Cloos J. Cell sensitivity assays: the MTT assay. Methods Mol Biol 2011; 731: 237-45.

33. Repetto G, del Peso A, Zurita JL. Neutral red uptake assay for the estimation of cell viability/cytotoxicity. Nat Protoc 2008; 3: $1125-31$.

34. Speit G, Hartmann A. The comet assay (single-cell gel test): a sensitive genotoxicity test for the detection of DNA damage and repair. DNA Repair Protocols 1999; 113: 203-12.

35. Spigoni V, Cito M, Alinovi R, Pinelli S, Passeri G, Zavaroni I, Goldoni M, Campanini M, Aliatis I, Mutti A, Bonadonna RC, Cas AD. Effects of $\mathrm{TiO}_{2}$ and $\mathrm{Co}_{3} \mathrm{O}_{4}$ nanoparticles on circulating angiogenic cells. PLoS One 2015; 10: e0119310.

36. Rajiv S, Jerobin J, Saranya V, Nainawat NM, Sharma A, Makwana P, Gayathri C, Bharath L, Singh M, Kumar M, Mukherjee A, Chandrasekaran N. Comparative cytotoxicity and genotoxicity of cobalt (II, III) oxide, iron (III) oxide, silicon dioxide, and aluminum oxide nanoparticles on human lymphocytes in vitro. Human Exp Toxicol 2015; 35: 170-83.

37. Jasmin G, Riopelle JL. Renal carcinomas and erythrocytosis in rats following intrarenal injection of nickel subsulfide. Laboratory Investigations 1976; 35: 71-8.

38. Kasprzak KS, Zastawny TH, North SL, Riggs CW, Diwan BA, Rice JM, Dizdaroglu M. Oxidative DNA base damage in renal, hepatic, and pulmonary chromatin of rats after intraperitoneal injection of cobalt(II) acetate. Chem Res Toxicol 1994; 7: 32935. 